Recherches. Le Département poursuit actuellement des travaux dans les domaines suivants:

- développement des techniques d'analyse démographique

- développement d'un cadre analytique dans le domaine de la sociologie de la fécondité et de la nuptialité

- étude de la transition démographique à partir de modèles de macro-simulation

- élaboration d'une documentation permanente sur les sources existantes pour l'analyse démographique de la nuptialité.

Publications. Le Département publie annuelement, depuis 1966, un 'recueil d'Etudes Démographiques' dans le cadre de la revue 'Recherches Economiques de Louvain'.

\title{
DEMOGRAPHIC REPORTS PUBLISHED BY THE STATISTICAL OFFICE OF THE CITY OF HELSINKI IN 1968-1970
}

'Sample census of population in Helsinki 1965', Statistics of the City of Helsinki, Helsinki, 1968, 8, 14, tables.

D:o VII:5. Contains some of the reports on the sample census mentioned in the following list. Helsinki 1969.

\section{Statistical Monthly Review of the City of Helsinki}

1968:1, p. 3-38. Mortality in groups of age and marital status in the years 1950/ $51-1960 / 61$.

$1968: 8$, p. 327-348. Number of 0-19 year olds by area, according to registration lists, in 1963 and 1967.

1969:1-2, p. 5-59. The structure of households in 1965 (results of the sample census).

1969:3, p. 79-109. The degree of crowding among households in 1965 (results of the sample census).

1969:5, p. 195-207. Moves within the city and migration into the city, by city area in 1966-67.

1969:7, p. 271-301. The population of Helsinki according to place of residence and place of work in 1965 (results of the sample census).

1969:9, p. 357-377. Suicides in Helsinki in the years 1956-65.

1969:10, p. 397-407. Mortality and length of life in Helsinki.

1970:1, p. 3-17. The effect of migration on the number of tax units in Helsinki.

1970:4, p. 123-136. Persons living in institutions and group quarters and persons lacking housing accommodation in 1965 (results of the sample census).

1970:9, p. 325-341. The turnover of inhabitants in two old city wards in Helsinki. 